\title{
Foreign National Women Arrested for Drug Trafficking: A Dynamic Socio-Penal Portrait
}

\author{
Raquel Matos, Manuela Ivone Cunha, and Joana Santos
}

\begin{abstract}
Women's imprisonment in Portugal was marked in the first decade of this century by the increasing proportion of foreign nationals. This circumstance had implications not only in the official statistics of crime, contributing to a great preponderance of drug trafficking but also in the dynamics of women's prisons and in the social discourses that associate immigration and crime. The present study is part of a research project on life trajectories of foreign national prisoners in Portugal, and it aims to analyze the social, demographic, criminal, and penal dimensions of female foreign nationals arrested in the country for drug trafficking. To this end, we collected and statistically analyzed data from 148 individual case files of foreign women prisoners. Results show the existence of at least two different scenarios of foreign national women arrested for drug trafficking in Portuguese prisons: on the one hand, women who come from European or South American countries, who did not live in Portugal, and who are held by international trafficking (drug couriers) and, on the other hand, women from African countries living in Portugal and arrested for drug trafficking practiced mainly in the country. These results allow us to deconstruct the idea that the high proportion of foreign national women in our prisons is unequivocally related to the phenomenon of immigration. Furthermore, results validate the importance of understanding, through qualitative research, these women's pathways to imprisonment in a foreign country.
\end{abstract}

\footnotetext{
R. Matos $(\bowtie) \cdot$ J. Santos

Universidade Católica Portuguesa - Research Centre for Human Development,

Porto, Portugal

e-mail: rmatos@porto.ucp.pt
}

M. I. Cunha

Center for Research in Anthropology (CRIA), Universidade do Minho, Braga, Portugal 


\section{Introduction}

In the history of criminology, studies on women who commit crimes have been fewer than studies on male offenders (Matos, 2008, 2018; Matos \& Machado, 2012). It is noticeable that the former studies not only are comparatively fewer but are also biased as they take for granted and reinforce stereotyped social discourses about women (Matos \& Machado, 2012; Smart, 1977). The proposals to understand the female imprisonment experience are also scarce, being one of the most neglected topics from the perspective of knowledge building and in terms of political action (Matos, 2008). Throughout time, studies on women's prisons were based on a permanent comparison with men's prison universe, whose topics and issues were taken as the main reference (Almeda, 2003; Azaola, 2007; Carlen, 2002; Cunha, 1994, 2007). A shift occurs with the emergence and consolidation of feminist perspectives on criminology, which suggest the development of studies that take the gender variable into consideration and which set a milestone in criminology from a methodological point of view, trying to give voice to the women's experiences (Matos \& Machado, 2012). At the international scene, several works on female criminality (e.g., Carlen, 1988; Chesney-Lind, 1997; Heidehnson, 1985) and on female imprisonment (e.g., Almeda, 2003; Azaola, 2007; Carlen, 2002) stand out. In Portugal, a few approaches on female criminality also emerged (e.g., Cunha, 2005, 2009; Leal, 2007; Matos, 2008), specifically addressing women's imprisonment. First, Carmo and Fráguas (2003), Manuela Ivone Cunha (1994, 2002), and Teresa Beleza (1990), addressed the women's experience in prison or the way the criminal system treats women. More recently, a large number of studies have been developed in Portugal in order to gain a clearer understanding of this field of research (e.g., Cunha \& Granja, 2014; Gonçalves \& Lopes, 2004; Granja, 2016; Matos, 2016, 2018).

\section{Drug Trafficking Within the Contexts of Criminality and Women's Imprisonment in Portugal}

By the end of the twentieth century, Portugal ranked first when it comes to drug offenses and female imprisonment rates among European countries (Cunha, 2005). Given the centrality of drug-related crimes in women's convictions, ${ }^{1}$ both in Portugal and worldwide, the rates of imprisoned women tend to be analyzed considering the variations in the arrests related to this type of crimes. In fact, it is a persistent statement that drug trafficking is the most common crime among women prisoners, both at a national level (e.g., Cunha, 2002; Matos, 2016, 2018) and at an international

\footnotetext{
${ }^{1}$ Official statistical data released by the General Directorate of Rehabilitation and Prison Services (DGRSP) in 2015 shows that from a total of 653 women serving time in jail, 257 (39.4\%) are convicted of drug trafficking.
} 
level (e.g., Almeda, 2003). It is then justified a deeper analysis on the drug-trafficking crime. To begin with, it matters to distinguish the retail market from the wholesale market; this distinction involves differences in the turnover but not in the dimension or structure of the organization in charge: contrary to popular belief, both levels are operated by small and poorly structured organizations, as well as by larger and most structured organizations (Cunha, 2001, 2005). It is also important to distinguish the organization modes around trafficking, in particular the freelance model, where cooperation, though accepted, is not long-lasting, and the business model, where the trafficking agents are strongly organized under close supervision and control and obeying to a strict hierarchy (Johnson et al., 1992, cit. in Cunha, 2001).

Over the nineties, the American and European retail narco-markets went through change, evolving from a freelance model into an entrepreneurial model (Cunha, 2002, 2005). As far as the Portuguese case is concerned, the mutation occurred in the opposite direction; today the freelance model still prevails in the Portuguese retail trafficking (Cunha, 2002, 2005). Looking at the evolution in women prisoners in Portugal and its relation to drug trafficking, we realize that while during the eighties women arrested for drug trafficking were mainly "drug couriers," in the nineties they were more frequently domestic trafficking agents. According to Manuela Ivone Cunha, "the transit traffic, materialized in that character once so frequent in Tires called the 'drug courier' arrested at the airports, seems to be replaced by the domestic trafficking as a cause of women's imprisonment" (2002, p. 66). There was a changing pattern in this scenario with the increasing proportion of foreign national women among female prisoners in Portugal during the first decade of the twentyfirst century ${ }^{2}$ (Matos, 2016). However, the extension of this change was not due to the increase in the numbers of imprisoned foreign nationals or to the crimes perpetrated by them; rather, it was due to an overall decrease in the female prison population (from around $10 \%$ in the end of the nineties to less than $6 \%$ in the end of this century's first decade). Given the stronger impact on the national rather than on the foreign national imprisoned population - as the former is the majority-such decrease caused the proportion of foreigners to stand out again, even though the overall population did not change. ${ }^{3}$

The retail trafficking in Portugal has been depicted as significantly less violent than in other countries, hence representing less physical risks for the actors that gravitate around this activity (Cunha, 2005). This characteristic of the drug market in Portugal combined with a greater autonomy to decide where, when, and how to sell drugs, in accordance with a freelance model, seem to favor women's participation in drug trafficking (e.g., Jacobs \& Miller, 1998; Morgan \& Joe, 1997, cit. in Cunha, 2009). The transition from a business model to a freelance model in Portuguese narco-markets seems to have increased the opportunities for women in trafficking. Women could get started on their own in dealing as freelancers, obtain-

\footnotetext{
${ }^{2}$ This proportion rose from $18 \%$ in 2002 to $30 \%$ in 2008 (Matos, 2016).

${ }^{3}$ This hypothesis when we look at the numbers of female prisoners in absolute terms: in 2000 there were 138 female prisoners among a total of 1206 women imprisoned in Portugal; in 2010, the foreign women were 183 out of a total of 623 female prisoners (cf. Justice Statistics).
} 
ing drugs on a loan or consignment basis through neighborhood networks. The accomplishment of this type of business is signed as a way for women to access financial resources in socially unfavorable contexts, frequently to support their family (Almeda, 2003; Azaola, 2007; Cunha, 2002; Torres \& Gomes, 2002). These women start developing their activity connected to trafficking from family and friendship relationships, making use of close solidarities among the existing social networks (Cunha, 2002, 2005). Portugal appears to present an association between the high number of women prisoners arrested for trafficking and the social context they come from; in the face of poor school and professional qualifications, these women perceive drug trafficking as one of the few ways available to access financial resources (Cunha, 2001; Torres \& Gomes, 2002). This argument explains the situation of adult women better, but it applies to the younger ones as well (Matos, 2018). In fact, there are empirical data showing that while some young women associate trafficking to drug addiction or to marital violence, others face trafficking as a business possibility (Matos, 2018).

Considering the international scene, women seem to be starring a small-scale trafficking, assuming quite often the role of "drug courier" (Miranda \& Palomo, 2007). In this role, often under the supervision of male figures, women become more vulnerable to detention through the formal control mechanisms and, as a consequence, to harsher sentences inherent to drug policies (Almeda, 2003; González, 2007; Miranda \& Palomo, 2007). To a certain extent, this explains the significant amount of foreign national women arrested for international drug trafficking when compared to male prisoners (Miranda \& Palomo, 2007). In fact, as previously mentioned, today's scenario of imprisoned women in Portugal shows a growing proportion of foreign national women, mostly arrested for the crime of drug trafficking. International trafficking, the most common offense among this group of women, is highlighted again. The foreign nationals are once again a relevant segment of female prison population convicted of trafficking. According to the DGRSP statistics reporting to the end of 2015, among the women convicted of drug trafficking, $37 \%$ were foreigners. A possible return to a greater preponderance of international trafficking, as we suggested, and in line with the hypothesis previously formulated, may be due to the general decline of the numbers of female prisoners in Portugal, rather than to a significant increase of international trafficking in absolute terms. Domestic trafficking may then appear proportionally less represented as the general decline of the female prison population tends to be more significantly reflected on the national female prison population. 


\section{Drug Trafficking in the Context of Foreign Nationals in Prison}

Prison statistics reveal that, in the first decade of this century, the proportion of foreign national women prisoners increased significantly, in line with European trends (Hostettler \& Achermann, 2008; Matos, 2016). Data also show that the number of foreign female prison population is proportionally higher than the foreign male prison population (Cunha, 2010; Seabra \& Santos, 2006; Torres \& Gomes, 2002). The increase in the imprisonment rates of foreign national women (Hostettler \& Achermann, 2008) follows their greater incidence on drug trafficking, which prevails as the top crime committed by foreign citizens arrested in Portugal (Rocha, 2001). Drug trafficking seems to enhance the number of foreign women in European prisons, and Portugal is no exception. Official data indicate that by the end of 2018, from the 96 convicted foreign national women in prison, 36 (37.5\%) committed this type of crime. As far as the male foreign nationals are concerned, from a total of 1259 , only $221(17.5 \%)$ were convicted of the crime of drug trafficking. Consequently, women seem to contribute more to the prevalence of trafficking among the crimes motivating the imprisonment of foreign national citizens in Portugal. ${ }^{4}$

Several studies have been carried out with the purpose of characterizing the imprisonment of foreign citizens in Portugal (e.g, Cunha, 2010; Gomes, 2014; Guia, 2008; Matos, 2016; Rocha, 2001; Santos, 2010; Seabra \& Santos, 2005, 2006). Based on these studies' findings, together with official data from the DGRSP, it is possible to make a brief description of the foreign nationals in Portuguese prisons, both in sociodemographic and penal terms. As far as age is concerned, most foreign citizens in custody in Portugal range from 30 to 39 years old. ${ }^{5}$ Regarding nationality, data collected between 1994 and 2003 reveal that most foreigners held in Portuguese prisons come from Portuguese-speaking African countries (PALOP) and Brazil; however, in 2006, the nationalities represented the most were Brazil, Ukraine, and Spain (Seabra \& Santos, 2006). Recent data from $2018^{6}$ indicate that the majority of foreign national prisoners (53.8\%) come from African countries (in particular Cape Verde), followed by European countries $(24.1 \%)$, in particular Romania and Spain, and South American countries (20.2\%) (especially Brazil). Concerning school qualifications, data show that, when compared to Portuguese prisoners, a higher number of foreign nationals attended basic education and higher education (Matos, 2016). Available data also show that a higher proportion of foreign national women attended or completed a university degree, compared with Portuguese women prisoners. Generally speaking, the foreign female prisoners also show a higher level of school qualifications when compared with what is depicted

\footnotetext{
${ }^{4}$ Cf. statistical 2018 data from the DGRSP.

${ }^{5} \mathrm{Cf}$. statistical 2018 data from the DGRSP.

${ }^{6} \mathrm{Cf}$. statistical 2018 data from the DGRSP.
} 
in the literature for the majority of incarcerated women (Matos, 2008; Matos \& Barbosa, 2015).

From a penal point of view, it is noticeable that both pretrial detention and prison sentences are applied more frequently to non national citizens than to Portuguese citizens (Seabra \& Santos, 2006). The explanation for this trend is threefold. To begin with, the Code of Criminal Procedure establishes as compulsory pretrial detention in the case of crime suspects without permission to remain in the country. The second reason relates to the fact that foreign nationals usually commit crimes that are the object of prison sentences exceeding three years (for instance, drug trafficking), and in that situation pretrial detention is also compulsory. At last, non national citizens are considered to have a higher risk of escaping (Seabra \& Santos, 2005, 2006; Trombik, 2007).

A few empirical studies addressing specifically foreign national women under arrest in Portugal show that most women are in prison due to drug trafficking (e.g., Santos, 2010). A study carried out with a sample of 56 foreign national women in the North of the country shows that 47 were arrested for the crime of drug trafficking, mostly as drug couriers across countries (Santos, 2010). Despite the presentation and discussion of empirical data and the continuous improvement of the official statistics from the Portuguese justice system, the need to carry out a current and more exhaustive characterization of foreign nation women in prison is acknowledged. It is particularly necessary to understand where do they come from, what connects them to the country of destination, and what their life and crime paths are up until imprisonment in a Portuguese prison.

\section{Female Foreign Nationals Arrested for Drug Trafficking: Sociodemographic and Criminal Trends}

The study we hereby present is part of a larger research project on the life paths of foreign women prisoners in Portugal (Matos, 2016; Matos \& Barbosa, 2015).

The sample encompasses 148 foreign national women in Portuguese prisons, aged 21 to 66 years old. The majority comes from African countries (56, 37.8\%), European countries $(47,31.8 \%)$, and Central and South American countries (37, $27.6 \%)$.

Concerning data collection, we analyzed the individual files of foreign national women in the Portuguese prison system (Matos, 2018), assuring their anonymity and the confidentiality of the data collected. ${ }^{7}$ The analysis considered both sociode-

\footnotetext{
${ }^{7}$ The methodology used for data collection, the analysis of female prisoners' individual files, contains certain limitations. Namely, the fact that the majority of these women (66.9\%) did not live in Portugal prior to the detention, and for that reason it was difficult to have access to their eventual former legal and criminal record. Other difficulties rely on the divergences found between the Portuguese system and the system in force in their home countries, educational or labor divergences, for instance.
} 


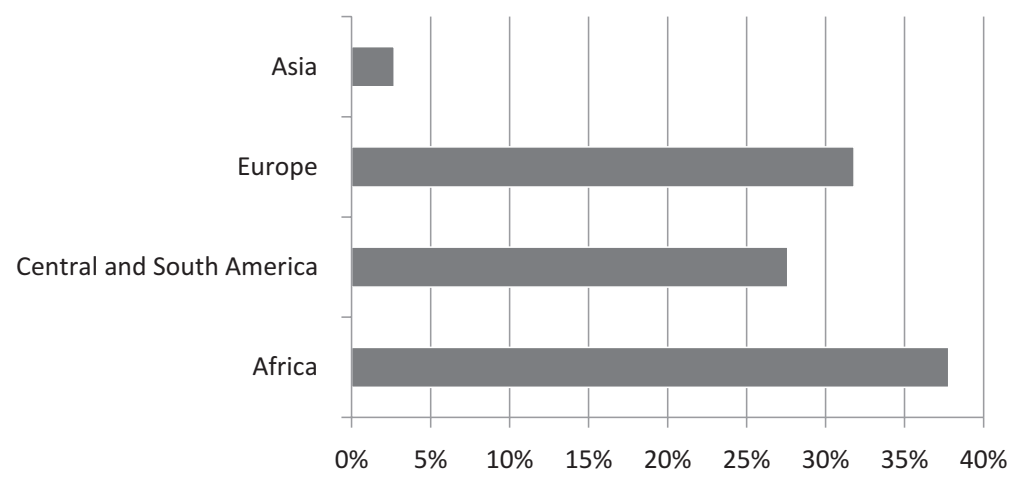

Fig. 1 Nationality (per continent)

mographic and criminal and legal data. The data collection took place in the first semester of 2010, in two Portuguese prisons. Data were statistically analyzed using SPSS software.

\section{Findings: Sociocriminal Profiles and Trafficking Trends}

The foreign national women prisoners were aged 21-66 years old, with and average age of 36, and with 49 and 30 years old as the most common ages. The predominant age range was $21-30$ years old $(70,37.8 \%)$, confirming the higher representation of foreign national women of younger age ranges when compared with Portuguese nationals (cf. DGRSP statistics). An explanation thereto may be the characteristics of retail trafficking in Portugal. Local, small-scale trafficking is different from international trafficking, i.e., drug transport and distribution, even at the "drug courier" scale. In the Portuguese context, retail trafficking is an activity easy to combine with domestic activities, as well as with older ages (Cunha, 2002, 2005). It is likely, then, to register a higher proportion of older women and that the age range within the overall participants in retail domestic trafficking is wider than the age range of those taking part in small-scale international trafficking. Regarding nationality, as Fig. 1 clearly shows, a higher number of female prisoners come from African countries (56, 37.80\%) and European countries (47, 31.80\%), followed by women from Central and South America $(37,27.6 \%) .{ }^{8}$ With regard to the countries, Cape Verde stands out $(38,25.7 \%)$, followed by Brazil $(22,14.9 \%)$ and Spain (18, $12.2 \%)$. When compared to the existing literature, this data reveal Europe's

\footnotetext{
${ }^{8}$ There is a record of female prisoners with dual nationality, for instance, one of the African prisoners also had Portuguese nationality, two women from Central and South America were also Portuguese and another had Spanish nationality as well. The dual nationality situations reveal, on the one hand, these women's birth place (Africa or America) and, on the other hand, their living place (Europe).
} 


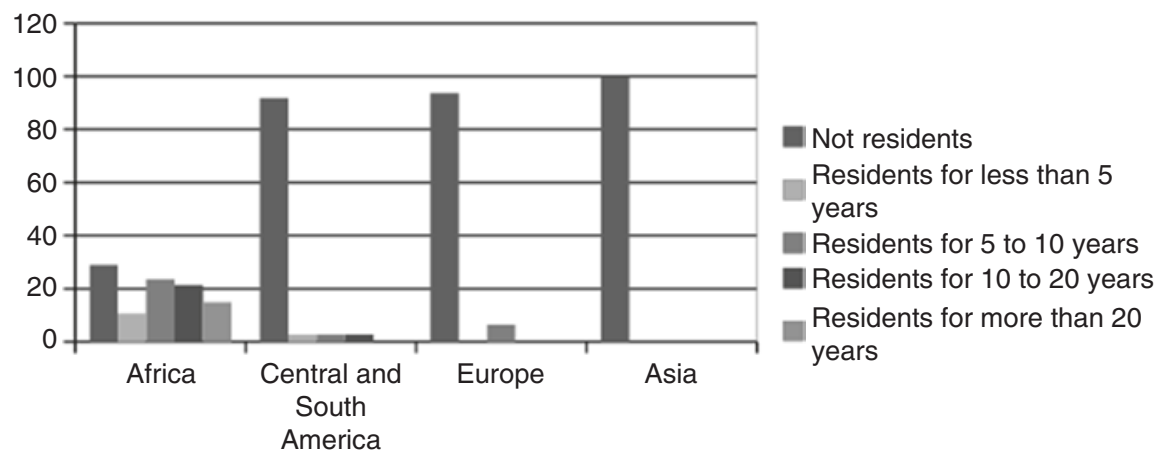

Fig. 2 Residence in Portugal vs. Nationality

significant predominance. This is a recent trend, initiated in the last decade, as previously foreign nationals came mostly from Portuguese-speaking African countries (PALOP) and from Brazil (Seabra \& Santos, 2006).

As far as school qualifications are concerned, two different scenarios were evidenced. On the one hand, the number of female prisoners $(36,24.32 \%)$ who completed secondary education or attended university $(11,7.4 \%)$ is considerable. On the other hand, the number of women who completed primary school is also remarkable $(33,22.29 \%)$, as well as the number of illiterate women or women who only know how to read and write $(14,9.4 \%)$. If we consider nationality, we realize the first scenario receives contributions mostly from women from European countries, together with a few South American women; for the scenario of lower school qualifications contribute above all female prisoners from African and South American countries. It is noticeable that we do not find such medium or high-education level in the Portuguese female prison population (e.g., Cunha, 2002; Matos, 2018); the proportion of foreign national women inmates with secondary education was higher than registered for Portuguese prisons. ${ }^{9}$ But we do realize that this is not an exclusive reality, as it is possible to find in Portuguese prisons women convicted of drug trafficking that come from abroad and have low school qualifications.

Prior to detention, the most common occupations of the women in our sample were related to trade $(43,29 \%)$, in particular street vendors, and related to domestic work $(22,14.9 \%)$. Both these job occupations were represented the most, regardless of the place where the women lived prior to detention-in Portugal, in their home country, or in any given country (Fig. 2).

Most female prisoners were not living in Portugal at the time they were arrested $(99,66.9 \%$ (cf. Fig. 4). From the 49 (33.1\%) women who did live in Portugal prior to detention, the residence time varied from 5 to 20 years, though the range from 5 to 10 years was slightly superior $(36.6 \%$ vs. $29.3 \%)$ to the range from 10 to 20 years. A combined analysis to residence and nationality (cf. Fig. 3) shows that most African-born women lived in Portugal (39, 70.9\%), while those from Central and

${ }^{9}$ Official statistical data from the DGRSP shows the percentage of Portuguese female prisoners who completed higher education was just $2.1 \%$, in 2015. 
Fig. 3 Place of detention

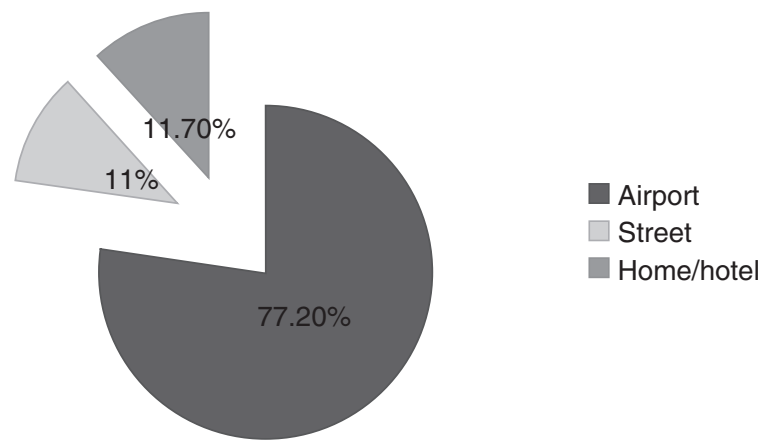

South America and Europe were mostly nonresidents $(91.9 \%$ and $93.6 \%$, respectively). The analysis of this data shows the diversity in the possibilities to contact or connect to Portugal. Many women had no contact whatsoever with the country prior to the detention; others were actually living in Portugal, though not for long; and another group was living in Portugal for over 10 years (in some cases over 20 years, actually), though keeping foreign nationality.

The airport emerged as the place where most women are caught $(105,77.2 \%)$, followed by public thoroughfare and in-house arrest (cf. Fig. 3). By crossing the variables of the detention spot with the place of residence prior to the arrest, we can again take into consideration two different scenarios to characterize foreign national women: on the one hand, women who did not live in Portugal and were caught being "drug couriers" and, on the other hand, women who did live in Portugal and were arrested in some other places (public thoroughfare, house, hotel/inn). In this last scenario, different types of trafficking must be considered, given the fact that the detention spot does not exclude at once "domestic" trafficking or international trafficking.

Looking at the legal situation, 124 women were convicted (83.8\%), and 24 remanded in custody (16.20\%). Considering all of the 124 women already convicted, most of them awaited for trial in prison $(114,77 \%)$. From a penal perspective, we conclude that pretrial detention as a legal measure of constraint is very often applied to foreign nationals due to the esteemed risk of escape (Seabra \& Santos, 2005, 2006; Trombik, 2007) and due to the fact that they commit crimes that receive prison sentences exceeding three years. Both circumstances apply to the participants in our study, who, given their nationality and their trafficking offenses, are most likely to undergo pretrial detention.

An analysis of the prison sentences shows that the average sentence is 3.09 years $(S D=0.477)$, ranging from 1 to 12 years. Figure 4 reveals the most common sentences range from three to six years $(101,81.5 \%)$. Lower percentages refer to sentences ranging from six to nine years $(14,11.3 \%)$. We confirmed that 42 women prisoners $(28.4 \%)$ were also charged with deportation as supplementary penalty.

The severity of the sentences must be discussed taking into account the types of offenses committed by the foreign national women. It is acknowledged that justice systems tend to be particularly intolerant when it comes to drug trafficking, register- 


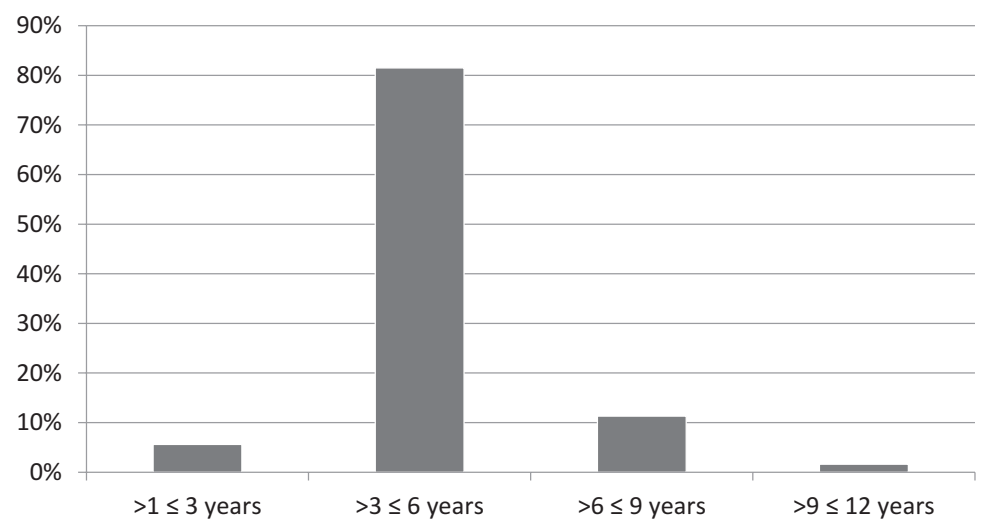

Fig. 4 Sentences

ing a higher number of detentions and applying longer sentences for this type of offenses, in Portugal and in other countries (e.g., Almeda, 2003; Cunha, 2002). However, our study revealed a smaller proportion of more severe sentences when compared with the sentences of female prison population as a whole. The most severe sentences are related to types of crimes, less represented in our study, in particular crimes against people and crimes against property, as these tend to be less frequent among foreign national prisoners. ${ }^{10}$

Finally, as this study focuses on drug-related crimes, we have tried to characterize drug use prior to detention and observed that most women $(118,84.9 \%)$ were not identified as drug users in their personal files. Among the 21 (15.1\%) women prisoners whose files mentioned drug use before getting to prison, most of them used the so-called "hard" drugs (e.g., cocaine, heroin) and tended to use multiple substances. In former studies on criminality perpetrated by women in Portugal, drug trafficking did not emerge as inevitably related to drug use, especially when compared to the male prison population (e.g., Cunha, 2002; Matos, 2008). So the drug-trafficking crime tends to be associated with opportunities that these women find in their social contexts providing them a better economic situation, rather than with problematic drug use, (Almeda, 2003; Azaola, 2007; Cunha, 2002, 2005; Matos, 2008; Torres \& Gomes, 2002).

\section{Final Remarks}

A preliminary approach to the findings indicates the existence of two different scenarios regarding the imprisonment of foreign national women for drug trafficking in Portugal. On the one hand, several women, mostly from European or South American countries, did not live in Portugal before getting to prison. It seems that

\footnotetext{
${ }^{10} \mathrm{Cf}$. statistical data from the DGRSP.
} 
these women were in Portugal merely due to the fact that they were arrested in this territory, having no connection to the country where they "happened" to be imprisoned. On the other hand, other foreign national women prisoners kept a more or less continuous or consolidated connection to Portugal, expectedly because they lived in the country or as a consequence of this fact. These were mostly African-born women, quite often living in Portugal for over 10 years. In these cases, the detentions took place on public thoroughfare more frequently, so the "domestic", freelance type of trafficking was very likely (Cunha, 2005), though the possibility that these women were international trafficking agents cannot be set aside.

Distinct forms of participation in the narco-trafficking market seem to be available for women: while some accepted to be "drug couriers", and were arrested in a country different from their own, others, living in Portugal, were also "drug couriers" or joined a freelance type of trafficking, possibly having access to drugs through neighborhood networks, and preparing themselves the product to resell or helping male partners in one or another transaction (Cunha, 2005).

This study does not shed light on, as it is being documented on studies about women's criminality and imprisonment, whether these women play a submissive role in the drug trafficking business, taking part in trafficking under supervision from male figures, hence performing more vulnerable roles (Miranda \& Palomo, 2007). But considering the description we were able to do based on the available data, we anticipate that these women may have played a more vulnerable role, thus being exposed to detention in a foreign country.

To sum up, we make two final remarks. The first one is related to the common narrative associating immigration and crime. In dominant social representations, the 'foreigner', the immigrant specifically, is considered as more willing to join criminal activity, so it is common to hear that immigration is related to criminality (Lages, Policarpo, Marques, Matos, \& António, 2006; Seabra \& Santos, 2006). However, empirical studies show that nonnational citizens do not present higher rates of criminal behavior, particularly if only country residents are taken into account (Guia, 2008). Certain discrepancies in crime involvement rates only reflect the biasing effect caused by the disparity of the corresponding demographic structures. When age, gender, and labor integration are taken into consideration between both populations, the discrepancy between national and foreign residents disappears and the crime rates actually reveal themselves as identical (Seabra \& Santos, 2005).

If we consider the fact that Portuguese prisons register a high rate of foreign national women, it is important to point out that our analysis showed that such rate is not related to immigration flows. As previously mentioned, the majority of the foreign national women in our study were not immigrants. Indeed, we found women who had no connection to Portugal and others who lived in the country for quite a long time. These latter seem to come close to Portuguese prisoners in terms of demographic, legal, and criminal characteristics (e.g., Cunha, 2002; Matos, 2008).

In future studies, it will be important to go beyond the superficial and limited data under analysis, which only allowed to glimpse, frame, and distinguish in general terms the profiles of women arrested for drug trafficking. 


\section{References}

Almeda, E. (2003). Mujeres encarceladas. Barcelona: Ariel.

Azaola, E. G. (2007). Género y justicia penal en México. In E. Samaranch \& E. González (Eds.), Mujeres y Castigo: Un enfoque sócio-jurídico y de género (pp. 27-65). Madrid: Dykinson.

Beleza, M. T. (1990). Mulheres, direito, crime ou a perplexidade de Cassandra. Lisboa: Faculdade de Direito de Lisboa.

Carlen, P. (1988). Women, crime and poverty. Milton Keynes: Open University Press.

Carlen, P. (2002). Introduction: Women and punishment. In P. Carlen (Ed.), Women and punishment: The struggle for justice (pp. 3-20). Devon: Willan Publishing.

Carmo, I., \& Fráguas, F. (2003). Puta de Prisão. Lisboa: Publicações Dom Quixote.

Chesney-Lind, M. (1997). The female offender. Girls, women and crime. Thousand Oaks: Sage Publications.

Covington, S. S. (1998). Women in prison: Approaches in the treatment of our most invisible population. Women and Therapy Journal, 21(21), 1-11.

Cunha, M. I. (1994). Malhas que a reclusão tece. Questões de identidade numa prisão feminina. Lisboa: CEJ.

Cunha, M. I. (2001). Do tráfico retalhista em Portugal: As redes da semi-periferia. Themis: Revista da Faculdade de Direito da Universidade Nova de Lisboa, 2(4), 41-60.

Cunha, M. I. (2002). Entre o Bairro e a Prisão: Tráfico e trajectos. Lisboa: Fim de século.

Cunha, M. I. (2005). From neighborhood to prison: Women and the war on drugs in Portugal. In J. Sudbury (Ed.), Global lockdown: Imprisoning women (pp. 155-165). New York and London: Routledge.

Cunha, M. I. (2007). A reclusão segundo o género. Os estudos prisionais, a reclusão de mulheres e a variação dos contextos da identidade. In Humana Global (Ed.), Educar o Outro- As Questões de Género, dos Direitos Humanos e da Educação nas Prisões Portuguesas (pp. 81-88). Coimbra, Portugal: Publicações Humanas.

Cunha, M. I. (2009). Las mujeres y la economia comparada de las drogas. In M. E. S. de Garay (Ed.), Crimen, Castigo y Género: Ensayos Teóricos de un Debate en Construcción (pp. 127135). Guadalajara, México: Centro Universitário de Ciências Sociales y Humanidades, Universidad de Guadalajara.

Cunha, M. I. (2010). Race, crime and criminal justice in Portugal. In A. Kalunta-Crumpton (Ed.), Race, crime and criminal justice: International perspectives (pp. 144-161). New York: Palgrave MacMillan.

Cunha, M. I., \& Granja, R. (2014). Gender asymmetries: Parenthood and confinement in two Portuguese prisons. Champ Pénal/Penal Field (Vol. XI). Parentalités enfermé.

Gomes, S. (2014). Caminhos para a prisão: uma análise do fenómeno da criminalidade associada a grupos estrangeiros e étnicos em Portugal. Famalicão: Ed. Húmus.

Gonçalves, R., \& Lopes, M. (2004). Mulheres na prisão. Percursos em Família. Polícia e Justiça: Família, Violência e Crime, III, 153-168.

González, E. B. (2007). Mujer inmigrante y sistema penal en España: La construcción de la desigualdad de género en el sistema penal. In E. Samaranch \& E. González (Eds.), Mujeres y castigo: Un enfoque sócio-jurídico y de género (pp. 105-131). Madrid: Dykinson.

Granja, R. (2016). Beyond prison walls the experiences of prisoners' relatives and meanings associated with imprisonment. Probation Journal, 63(3), 273-292.

Guia, M. J. (2008). Imigração e Criminalidade: Caleidoscópio de Imigrantes Reclusos. Coimbra: Almedina.

Heidehnson, F. (1985). Women and crime. London: Macmillan Press.

Hostettler, U., \& Achermann, C. (2008). Cidadãos estrangeiros em duas prisões na Suíça. Vida prisional, reabilitação e destino pós-reclusão. In M. I. Cunha (Ed.), Aquém e Além da prisão. Cruzamentos e perspectivas. Lisboa: $90^{\circ}$ Editora.

Jacobs, B., \& Miller, J. (1998). Crack dealing, gender, and arrest avoidance. Social Problems, 45(4), 550-569. 
Johnson, B., Hamid, A., \& Sanabria, H. (1992). Emerging models of crack distribution. In T. Mieczkowski (Ed.), Drugs, crime, and social policy: Research, issues, and concerns (pp. 56-78). Boston, MA: Allyn and Bacon.

Lages, M., Policarpo, V., Marques, J., Matos, P., \& António, J. (2006). Os imigrantes e a população portuguesa imagens recíprocas. Análise de duas sondagens. Lisboa: Alto Comissariado para a Imigração e Minorias Étnicas (ACIME).

Leal, J. (2007). Crime no feminino. Trajectórias Delinquenciais de Mulheres. Coimbra: Edições Almedina.

Matos, R. (2008). Vidas raras de mulheres comuns: Percursos de vida, significações do crime e construção da identidade em jovens reclusas. Coimbra: Almedina.

Matos, R. (2016). Trajectories and identities of foreign national women: Rethinking prison through the lens of gender and citizenship. Criminology and Criminal Justice, 16, 350-365.

Matos, R. (2018). Gender and crime in the life pathways of young women offenders: Contrasting the narratives of girls and professionals. In S. Gomes \& V. Duarte (Eds.), Female crime and delinquency in Portugal. Cham: Palgrave Macmillan.

Matos, R., \& Barbosa, M. (2015). Mulheres de nacionalidade estrangeira detidas em Portugal. Breve caracterização de trajetos de vida e envolvimento no crime. In S. Gomes \& R. Granja (Eds.), Mulheres e Crime Perspectivas sobre intervenção, violência e reclusão. Famalicão: Editora Húmus.

Matos, R., \& Machado, C. (2012). Criminalidade feminina e construção do género: Emergência e consolidação das perspectivas feministas na Criminologia. Análise Psicológica, XXX(1-2), $33-47$.

Miranda, M., \& Palomo, T. (2007). Mujeres non nacionales en prisión. In E. Samaranch \& E. González (Eds.), Mujeres y castigo: Un enfoque sócio-jurídico y de género (pp. 187-207). Madrid: Dykinson.

Morgan, P., \& Joe, J. A. (1997). Uncharted terrain: Contexts of experience among women in the illicit drug economy. Women and Criminal Justice, 8(3), 85-109.

Rocha, J. (2001). Reclusos Estrangeiros: Um estudo exploratório. Coimbra: Almedina.

Santos, J. (2010). Trajectórias de reclusas estrangeiras detidas pelo crime de tráfico de droga. Dissertação de Mestrado, Porto, Universidade Católica Portuguesa do Porto.

Seabra, M., \& Santos, T. (2005). A Criminalidade de estrangeiros em Portugal. Um inquérito científico. Lisboa: ACIME.

Seabra, M., \& Santos, T. (2006). Reclusos estrangeiros em Portugal - esteios de uma problematização. Lisboa: ACIME.

Smart, C. (1977). Women, crime and criminology: A feminist critique. London: Routledge \& Kegan Paul.

Torres, A. C., \& Gomes, M. C. (2002). Drogas e prisões em Portugal. Lisboa: CIES/ISCTE.

Trombik, E. (2007). L'incarcération dés détenus allemands en France: Perspectives et limites dês projects de réinsertion. Cham Pénal, IV. 